\title{
Samba II PCR testing for COVID-19 in pregnant women: a retrospective cohort study and literature review
}

\author{
Ruiling Xu' ${ }^{1}$, Tara Alicia Pauley ${ }^{1}$, Hannah Missfelder-Lobos ${ }^{1}$, Richard John Haddon², Ravindra Kumar Gupta ${ }^{3}$ and \\ Hsu Phern Chong ${ }^{1 *}$ (i)
}

\begin{abstract}
Background: Asymptomatic carriage of COVID-19 in pregnant women has been reported and could lead to outbreaks in maternity units. We sought to ascertain the impact of rapid isothernal nucleic acid based testing for COVID-19 in an unselected cohort of pregnant women attending our maternity unit. We also assessed the correlation between community prevalence and asymptomatic carriage.

Methods: Data for the retrospective cohort study were collected from a large UK tertiary maternity unit over a 4week period using computerised hospital records. Literature searches were performed across multiple repositories. COVID-19 prevalence was extracted from online repositories.

Results: Nasopharyngeal and oropharyngeal swabs were obtained from 457/465 (98\%) women during the study period. The median turnaround time for results was $5.3 \mathrm{~h}$ (interquartile range (IQR) $2.6-8.9 \mathrm{~h}$ ), with $92 \%$ of the results returned within $24 \mathrm{~h}$. In our cohort, only one woman tested positive, giving a screen positive rate of $0.22 \%$ (1/457; 95\% Cl: 0.04-1.23\%). One woman who tested negative developed a fever postnatally following discharge but was lost to follow-up. From our literature review, we did not find any correlation between asymptomatic carriage in pregnant women and the reported regional prevalence of COVID-19.

Conclusions: Testing using the SAMBA-II machine was acceptable to the vast majority of pregnant women requiring admission and had a low turnaround time. Asymptomatic carriage is low, but not correlated to community prevalence rates. Screening pregnant women on admission will remain an important component in order to minimise nosocomial infection.
\end{abstract}

Keywords: COVID-19, SARS-CoV-2, Pregnancy, Universal screening

\section{Background}

The World Health Organization (WHO) characterized Coronavirus disease 2019 (COVID-19) as a global pandemic caused by severe acute respiratory syndrome coronavirus 2 (SARS-CoV-2) in March 2020 [1]. The first case series was described by Huang et al. [2] where 41

\footnotetext{
* Correspondence: hsu.chong@nhs.net

'Department of Obstetrics \& Gynaecology, Rosie Maternity Hospital, Cambridge CB2 OSQ, UK

Full list of author information is available at the end of the article
}

patients were admitted to Jin Yin-Tan Hospital in Wuhan, China. Of the 41 confirmed cases, $98 \%$ had fever and $76 \%$ had a dry cough, all developed pneumonia. Deep sequencing of lower respiratory tract samples identified the viral genome to be from the coronavirus family and this was named (COVID-19). Cellular access is gained through a spike protein that binds to the angiotensin-converting enzyme 2 receptor (ACE2), and viral uptake is promoted by the type 2 transmembrane serine protease (TMPRSS2) [3]. Lauer reported a median

(c) The Author(s). 2021 Open Access This article is licensed under a Creative Commons Attribution 4.0 International License, which permits use, sharing, adaptation, distribution and reproduction in any medium or format, as long as you give appropriate credit to the original author(s) and the source, provide a link to the Creative Commons licence, and indicate if changes were made. The images or other third party material in this article are included in the article's Creative Commons licence, unless indicated otherwise in a credit line to the material. If material is not included in the article's Creative Commons licence and your intended use is not permitted by statutory regulation or exceeds the permitted use, you will need to obtain permission directly from the copyright holder. To view a copy of this licence, visit http://creativecommons.org/licenses/by/4.0/ The Creative Commons Public Domain Dedication waiver (http://creativecommons.org/publicdomain/zero/1.0/) applies to the data made available in this article, unless otherwise stated in a credit line to the data. 
5.7 days to fever onset (CI 4.9-6.8 days), and 97.5\% of cases had a fever within 12.5 days (CI 8.2-17.7 days of exposure) [4]. Importantly, COVID-19 often takes a prolonged disease course with viral load in throat and nose declining after the first week as antibody titres rise [5]. This can result in nucleic acid testing becoming negative after the first week, though neutralisation and SARS$\mathrm{CoV}-2$ antibodies are readily detectable in nearly all cases [6]. Asymptomatic carriage of COVID-19 was estimated to be $15 \%$ in general population [7] and Sutton et al. [8] reported that positive rate of $13.7 \%(29 / 210)$ among asymptomatic group and $87.9 \%$ (29/33) of pregnant women infected with SARS-CoV-2 were asymptomatic at presentation.

Identification of asymptomatic pregnant women with COVID-19 is important for several reasons. Firstly, identification of asymptomatic carriers would allow changes in the pathway of care so as to prevent nosocomial infections, reducing the risk of asymptomatic transmission to other pregnant women and also to healthcare workers $(\mathrm{HCW})$. Testing also enables early isolation and rationalisation of personal protective equipment (PPE). Thirdly, identification of viral carriage could allow closer monitoring both during and after delivery, consideration of low molecular heparin for prophylaxis of venous thromboembolism, and longer term follow-up.

SAMBA II is an isothermal point of care nucleic acid amplification based platform with a detection limit of around 250 genome copies/ml [9]. It has previously been clinically validated in parallel with standard reverse transcription polymerase chain reaction (RT-PCR) with sensitivity and specificity of $96.9 \%$ (95\% CI 84.2-99.9) and 100\% (95\% CI 96.9-100) for COVID-19, respectively. The median time to result has been significantly reduced from 26.4 h (IQR 21.4 to 31.4) for the standard lab RTPCR test to $2.6 \mathrm{~h}$ (IQR 2.3 to 4.8 ) for SAMBA II SARSCoV-2 test [10].

The aims of this paper are two-fold: to ascertain the incidence of asymptomatic carriage in our maternity unit using a rapid diagnostic testing platform; and to assess if the rate of carriage of COVID-19 in asymptomatic pregnant women correlated with peak local prevalence.

\section{Methods}

\section{Study design and setting}

Cambridge University Hospitals NHS Foundation Trust (CUH) covers a large geographical area with a total population of approximately 5 million people in the east of England. The Rosie Maternity Hospital is part of CUH, with an annual delivery rate of approximately 5500 women. All admissions to the Rosie Maternity Hospital were offered a nasopharyngeal (NP) and oropharyngeal (OP) swab for COVID-19. These included women who were required antenatal and postnatal admission to the obstetric wards, women attending the main delivery unit and birth centre, and women attending for elective Caesarean Section or cerclage insertion. All staff members received training prior to obtaining swabs. Samples were processed using the SAMBA II machine (Diagnostics for the Real World, Chesterford, UK) [11, 12]. Data were extracted for population demographics and symptomatology. Symptoms were defined as fever and or cough in line with Public Health England's advice at the time. Patients who were asymptomatic were defined as women who lacked a fever and/or cough from the time of testing to discharge. Turnaround time was defined as the time the swab was collected, to the time a result was uploaded onto the electronic hospital record. Where time entries were missing, electronic hospital notes were retrieved to check for a record of sample collection and availability of results. These were computed separately. Our study was registered as a service evaluation project and ethical approval was not required.

\section{Data and literature review}

We conducted a literature search from PubMed, Cochrane COVID-19 trials for published studies, MedRxiv for pre-prints and an unofficial online repository on $15 / 05 / 2020$ and updated on $07 / 08 / 2020$. Where datasets from the same institution were replicated in more than one publication, but with a larger sample size or longer duration, the publication with the largest sample size and/or duration was selected. Data were extracted for case definition, diagnostic test employed, duration of follow up, gestational age at the time of testing and turnaround time. In order to assess if the prevalence of COVID-19 positive symptomatic and asymptomatic pregnant women correlated with local prevalence rates, we extracted local population COVID-19 prevalence rates for each of the included studies from open source repositories (Supplementary information).

\section{Statistical analysis}

Data were analysed using GraphPad Prism version 5.00 for Windows, GraphPad Software, San Diego California USA, www.graphpad.com. Data were extracted by two reviewers ( $\mathrm{RX}$ and $\mathrm{HC}$ ), and disagreements were resolved by discussion with a 3rd reviewer (TP).

\section{Results}

\section{SAMBA-II results}

During the period 07/05-06/06 (4 weeks) 465 women attended the Rosie Maternity Hospital for obstetric indications. NP and OP swabs were obtained from 457/465 women upon admission (98\%). 18 (3.84\%) women had more than one swab taken either due to prolonged inpatient admission beyond 7 days, or reattendance within the 4 week period. Self-reported ethnicity was available 
for $99.5 \%$ of women. The majority of our population consisted of White British, Irish or European ancestery $(407 / 465,87.5 \%)$ and this is reflective of the local population in Cambridgeshire. The median gestational age at the time of the admission swab was 39 weeks (Interquartile range (IQR) 37-40 weeks). Six women (1.3\%) attended in the postnatal period due to obstetric concerns. The median duration of inpatient stay for all patients was two days (IQR $1-3$ ). The median duration of follow-up in the post-natal period was 5 days (IQR 3-9).

None of the women had a cough on admission. 37/465 women developed a fever either during labour or following delivery (7.9\%). All 37 women had a negative result on admission, and the fever was attributed to an obstetric cause. Two women were admitted with breathlessness on a background of cardiac disease. One woman developed symptoms of fever or sore throat four days after delivery. Advice from Public Health England at the time was to contact a national helpline and she was lost to follow up.

Only one woman in our cohort tested positive over this four-week interval. This woman had neither cough nor fever on admission, but had symptoms of altered taste and smell four weeks prior to her admission. To ensure that this was a true positive, NP and OP swabs were repeated using the SAMBA II machine (but not included in our current analyses for TAT) until she tested negative. As this patient remained symptom-free during admission, she would be the only true asymptomatic COVID-19, giving an asymptomatic carriage rate of $0.22 \%$ (1/457; 95\% CI: 0.04-1.23\%). Knowledge of her results enabled $\mathrm{HCW}$ to convert from using standard surgical masks, plastic aprons and gloves to full personal protective equipment when caring for this patient.

Result turnaround times (TAT) were verified and available for $432 / 457$ (94.5\%) samples. The median TAT was $5.3 \mathrm{~h}$ (IQR 2.6-8.9) (Fig. 1), with 93.9\% (429/457) of sample results returned within $24 \mathrm{~h}$. Where sample turnaround times were absent, these were due to an underestimation of turnaround times rather than a delay in sample processing. This information was gleaned from verbatim entries in the patient records regarding the sample obtained, and the results entered. As no specific record of time was entered, these were excluded from further analyses. A small percentage $(16 / 465,3.4 \%)$ of women declined to be swabbed on admission, 5 of them were in discomfort from labour therefore declined testing. No reasons were given for the remaining 11 women who declined testing.

\section{Literature review}

Four hundred and seven articles were screened for title and abstract and 46 full-text articles assessed for inclusion. 17 universal screening studies [13-29] (Table 1) were selected to assess if the prevalence of COVID-19 positive pregnant women correlated with local prevalence rates as these papers fulfilled our prespecified criteria above.

We found a correlation between the test positivity with the regional background prevalence rates of COVID-19. There was a direct correlation between the number of confirmed cases at the peak $\left(\mathrm{R}^{2}=0.41, p=0.0053\right)$ (Fig. $\left.2 \mathrm{~b}\right)$

Sample turnaround time

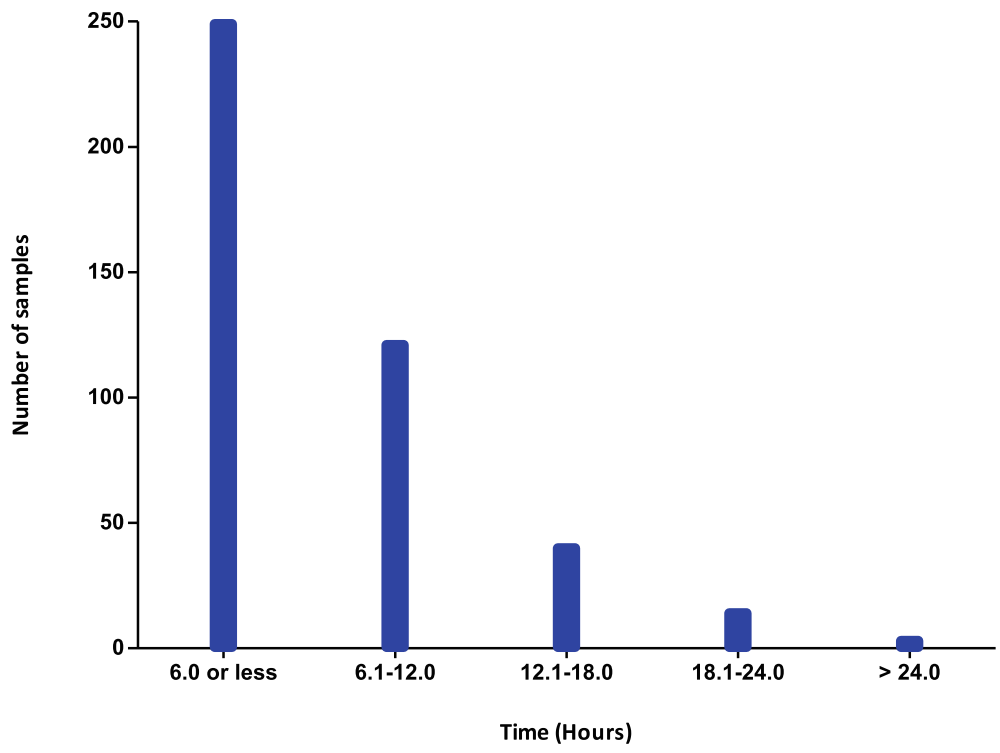

Fig. 1 Results turnaround times (TAT) from 432 SARS-CoV-2 testing samples, using SAMBA II for in-hospital testing 
Table 1 Community COVID-19 prevalence and asymptomatic carriage in pregnant women

\begin{tabular}{|c|c|c|c|c|c|c|c|c|c|c|}
\hline Author & $\begin{array}{l}\text { Region/ } \\
\text { Country }\end{array}$ & $\begin{array}{l}\text { Type of } \\
\text { study }\end{array}$ & $\begin{array}{l}\text { Peak } \\
\text { daily } \\
\text { case load } \\
\text { at start } \\
\text { of the } \\
\text { study } \\
\text { period } \\
\text { for } \\
\text { relevant } \\
\text { area }\end{array}$ & $\begin{array}{l}\text { Max } \\
\text { daily } \\
\text { case } \\
\text { load } \\
\text { during } \\
\text { study } \\
\text { period } \\
\text { for } \\
\text { relevant } \\
\text { area } \\
\end{array}$ & $\begin{array}{l}\text { Peak } \\
\text { daily } \\
\text { case load } \\
\text { the end } \\
\text { of the } \\
\text { study } \\
\text { period } \\
\text { for } \\
\text { relevant } \\
\text { area }\end{array}$ & $\begin{array}{l}\text { Number } \\
\text { of } \\
\text { pregnant } \\
\text { women } \\
\text { in study }\end{array}$ & $\begin{array}{l}\text { Number } \\
\text { tested } \\
\text { positive }\end{array}$ & $\begin{array}{l}\text { Number } \\
\text { asymptomatic } \\
\text { at the time of } \\
\text { admission } \\
\text { AND tested } \\
\text { positive }\end{array}$ & $\begin{array}{l}\text { Test } \\
\text { positivity } \\
\%\end{array}$ & $\begin{array}{l}\text { Proportion of } \\
\text { asymptomatic } \\
\text { test positive } \\
\%\end{array}$ \\
\hline Fassett & $\begin{array}{l}\text { California, } \\
\text { USA }\end{array}$ & $\begin{array}{l}\text { Observational } \\
\text { retrospective } \\
\text { study }\end{array}$ & 1261 & 1921 & 1921 & 3923 & 17 & 17 & 0.43 & 100.00 \\
\hline Gagliardi & $\begin{array}{l}\text { North of } \\
\text { Tuscany and } \\
\text { Liguria, Italy }\end{array}$ & Case series & 5210 & 6153 & 4053 & 533 & 3 & 2 & 0.56 & 66.67 \\
\hline Herraiz & $\begin{array}{l}\text { Madrid, } \\
\text { Spain }\end{array}$ & $\begin{array}{l}\text { Observational } \\
\text { retrospective } \\
\text { study }\end{array}$ & 6278 & 6740 & 2610 & 203 & 2 & 1 & 0.99 & 50.00 \\
\hline Naqvi & $\begin{array}{l}\text { California, } \\
\text { USA }\end{array}$ & Case series & 1104 & 1331 & 1268 & 82 & 1 & 0 & 1.22 & 0.00 \\
\hline LaCourse & $\begin{array}{l}\text { Washington, } \\
\text { USA }\end{array}$ & $\begin{array}{l}\text { Retrospective } \\
\text { cohort }\end{array}$ & 2 & 437 & 314 & 188 & 5 & 1 & 2.66 & 20.00 \\
\hline Ceulemans & $\begin{array}{l}\text { North East } \\
\text { Flanders, } \\
\text { Belgium }\end{array}$ & Case series & 683 & 2319 & 426 & 470 & 13 & 8 & 2.77 & 61.54 \\
\hline Miller & Illinois, USA & Case series & 1150 & 2023 & 2023 & 635 & 23 & 10 & 3.62 & 43.48 \\
\hline Ochiai & Tokyo, Japan & $\begin{array}{l}\text { Retrospective } \\
\text { analysis }\end{array}$ & 383 & 743 & 203 & 52 & 2 & 2 & 3.85 & 100.00 \\
\hline Campbell & $\begin{array}{l}\text { Connecticut, } \\
\text { USA }\end{array}$ & Case series & 377 & 1100 & 620 & 770 & 30 & 22 & 3.90 & 73.33 \\
\hline Khalil & London, UK & Cohort study & 822 & 1071 & 434 & 129 & 9 & 8 & 6.98 & 88.89 \\
\hline Yassa & $\begin{array}{l}\text { Istanbul, } \\
\text { Turkey }\end{array}$ & $\begin{array}{l}\text { Prospective } \\
\text { cohort }\end{array}$ & 2131 & 2936 & 1035 & 296 & 23 & 12 & 7.77 & 52.17 \\
\hline Prabhu & $\begin{array}{l}\text { New York, } \\
\text { USA }\end{array}$ & $\begin{array}{l}\text { Prospective } \\
\text { cohort }\end{array}$ & 2166 & 9909 & 6693 & 675 & 70 & 55 & 10.37 & 78.57 \\
\hline Doria & $\begin{array}{l}\text { Senhora da } \\
\text { Hora, } \\
\text { Portugal }\end{array}$ & Case series & 302 & 1516 & 514 & 103 & 12 & 11 & 11.65 & 91.67 \\
\hline Sutton & $\begin{array}{l}\text { New York, } \\
\text { USA }\end{array}$ & Cohort study & 2166 & 8775 & 8775 & 215 & 33 & 29 & 15.40 & 87.60 \\
\hline Buckley & $\begin{array}{l}\text { New York, } \\
\text { USA }\end{array}$ & Case series & 9073 & 9909 & 8064 & 307 & 50 & 50 & 16.29 & 100.00 \\
\hline Vintzileos & $\begin{array}{l}\text { New York, } \\
\text { USA }\end{array}$ & $\begin{array}{l}\text { Retrospective } \\
\text { cohort }\end{array}$ & 6555 & 9909 & 9410 & 161 & 32 & 21 & 19.88 & 65.63 \\
\hline London & $\begin{array}{l}\text { New York, } \\
\text { USA }\end{array}$ & $\begin{array}{l}\text { Retrospective } \\
\text { cohort }\end{array}$ & 73 & 9909 & 8064 & 156 & 68 & 22 & 43.58 & 32.35 \\
\hline
\end{tabular}

Data presented are in ascending order of the total proportion of pregnant women who tested positive. Data for peak daily reported COVID-19 prevalence at the start, during and end of the relevant study periods were retrieved from internationally published repositories [30-32]. This data was used to generate Figs. 2 and 3. NP- Nasopharyngeal, OP- Oropharyngeal

and end of the study period with those who tested positive $\left(R^{2}=0.48, p=0.002\right)$ (Fig. $2 \mathrm{c}$ ), but not with the number of confirmed cases at the start of the study period $\left(\mathrm{R}^{2}=0.004, p=0.82\right)$ (Fig. 2a). There was no correlation between the proportions of asymptomatic pregnant carriers with background infection rates (Fig. 3).
Only three papers reported turnaround time. Breslin et al. [33] reported an average of $8 \mathrm{~h}$ for 43 women screened [Conventional PCR, (New York, New York)] and LaCourse et al. [17] reported a median turnaround time of $2.5 \mathrm{~h}$ for rapid testing [DiaSorin Simplexa (MDX Liaison) EUA assay, $n=82$ women] and $7.1 \mathrm{~h}$ for routine PCR (Seattle, Washington). London et al. [29] reported 
A: Relationship between prevalence of COVID-19 in pregnant women and daily prevalence

\begin{tabular}{|c|}
\hline 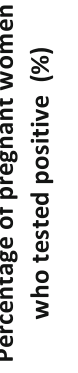 \\
\hline
\end{tabular}

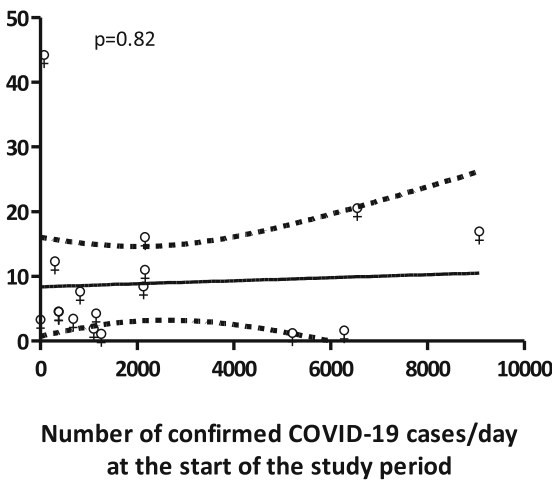

B: Relationship between prevalence of COVID-19 in pregnant women and maxium daily prevalence

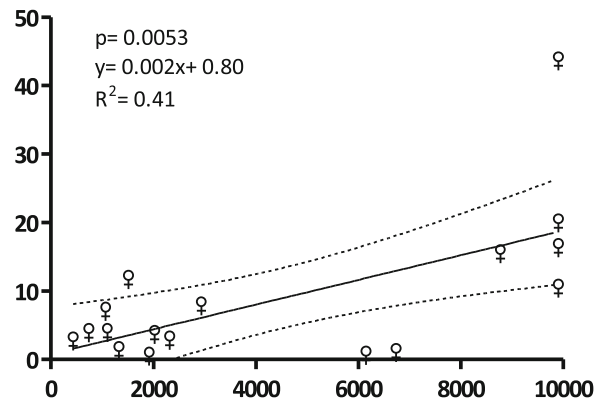

Number of confirmed COVID-19 cases/day

C: Relationship between prevalence of COVID-19 in pregnant women and maximum daily prevalence
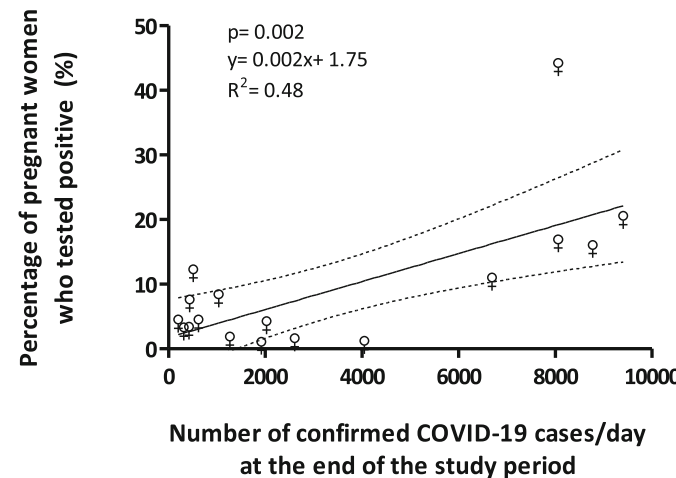

at the end of the study period
Fig. 2 Relationship between prevalence of COVID-19 in pregnant women and published peak prevalence. Data from Table 1 was used to generate Figure 2. Simple linear regression was performed to investigate the relationship between the prevalence of COVID-19 in pregnant women and peak daily community prevalence at three time points: the start of the study interval the maximum reported daily prevalence and the prevalence at the end of the study interval. The scatter plots demonstrated a positive correlation with the maximum reported daily prevalence rates during the study interval $\left(R^{2}=0.41\right.$, $p=0.0053)$ and towards the end of the study period $\left(R^{2}=0.48, p=\right.$ 0.002 ) but not with rates at the start $\left(R^{2}=0.004, p=0.82\right)$

an average turnaround time of $5 \mathrm{~h}$ using GeneXpert PCR in a cohort of 75 women (Brooklyn, New York).

\section{Discussion}

\section{Main findings}

Our work summarises existing literature on universal screening of asymptomatic carriage of COVID-19 in pregnant women with specific reference to the turnaround time of results, and local prevalence rates. The key findings of our study are threefold. We captured data on all attendances in a large UK maternity hospital and ours is the largest, to have reported turnaround times of less than $24 \mathrm{~h}$ in over $90 \%$ of samples returned. We were also able to demonstrate a high acceptability of COVID-19 screening amongst our maternity population with only $3 \%$ declining to be tested. Thirdly, ours is the first study to demonstrate the utility of point of care testing in an unselected cohort of pregnant women attending a large UK maternity unit.

Whilst the data are reflective of our maternity service, laboratory services were also processing samples from patients attending the accident and emergency department, and medical and surgical wards within a national health service. We were still able to achieve a short turnaround time of five hours. This allowed for changes to be made within postnatal care pathway, and escalation of the use of personal protective equipment. Testing of newborns could have also been performed had it been required.

The low positive screening rate in our cohort may be partly explained by the low rates of infection in the east of England (cumulative infection rate $0.42 \%$ ), in comparison to $1.27 \%$ in California and $2.12 \%$ in New York. As the pandemic evolved, advice and guidance were issued to pregnant women in the UK, who may have adopted behavioural changes that minimised interaction with the general public. Additionally, home working and minimising the commute to work could have protected them further. Interestingly, the proportion of asymptomatic carriers did not correlate with the regional infection rate. Possible explanations include variations in mask wearing, local test and trace strategies, movement control orders and specific advice on "shielding" in pregnant women [34].

Many hospitals introduced visiting restrictions during the lockdown, and ours was no different. Partners were 
A: Relationship between asymptomatic carriage of COVID-19 in pregnant women and initial local prevalence

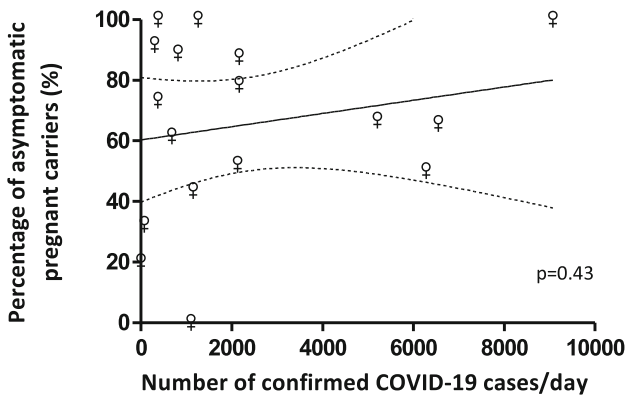

B: Relationship between asymptomatic carriage of COVID-19 in pregnant women and maximum local prevalence

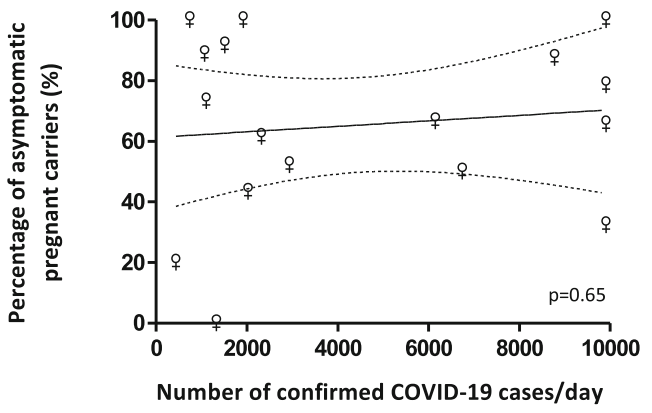

C: Relationship between asymptomatic carriage of COVID-19 in pregnant women and local prevalence

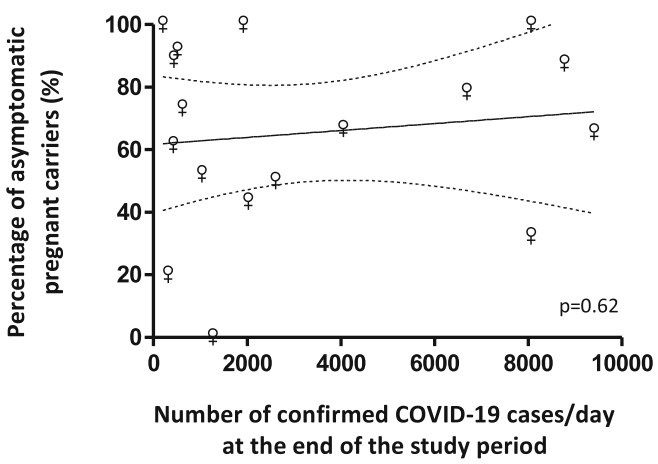

Fig. 3 Relationship between asymptomatic carriage of COVID-19 in pregnant women and local peak prevalence. Data from Table 1 was used to generate Figure 3. Simple linear regression was performed to investigate the relationship between the prevalence of COVID-19 in pregnant women and peak daily community prevalence at three time points: the start of the study interval, during and end of the study interval. The scatter plots demonstrated no correlation with the maximum reported daily prevalence rates at the start $\left(R^{2}=0.04\right.$, $p=0.44)$, during $\left(R^{2}=0.01, p=0.65\right)$ and end of the study intervals $\left(R^{2}=0.02, p=0.62\right)$

not allowed to attend the antenatal ward nor ultrasound scan appointments. Obstetric and non-obstetric face-toface clinic appointments were changed to phone appointments where possible, thus reducing footfall within the hospital premises. Staff working in clinical areas were required to wear personal protective equipment in the form of a surgical mask, gloves and aprons as a minimum, and FFP3 masks for aerosol generating procedures. Thus, pregnant women attending hospital should also be reassured, not only that asymptomatic carriage of COVID-19 is low, infection within the inpatient setting is low. Whether or not this is maintained against a backdrop of rising COVID-19 infections rates is unknown.

\section{Strengths and limitations}

We did not compare the test accuracy of the Samba-II machine in our population. However, this device has been tested previously in a cohort of over 1000 individuals and found to have $97 \%$ accuracy to conventional RT-PCR testing [10]. There is no reason to believe why it should perform differently in pregnant women. In contrast, GeneXpert PCR testing has been previously been validated on a much smaller cohort of less than 50 women [35]. We did not perform radiological investigations to look for manifestations of COVID-19 pneumonia, as some others have clinical diagnosis criteria as well as laboratory diagnosis [36, 37]. Women could therefore have a negative NP or OP result for COVID19, but have radiological changes. However, the likelihood of this is low. Although we had a high acceptability rate, we did not explore women's and staff views on screening for COVID-19, thus further research is required to evaluate this. For example, there may be a need to develop tests which are acceptable to women in labour, or training for hospital staff in contact tracing where women simply declined to be tested. In the interest of patient safety, we would suggest a conservative approach to patient pathways for women who decline testing so as not to result in contagion within the hospital setting.

We accept that anosmia and lack of taste can be considered a symptom of COVID-19 infection. However, we used pre-specified criteria for asymptomatic screening to ensure consistency in case definition so as not to exclude women screened prior to $18 / 5 / 2020$, when changes in symptom definition were published [38]. Indeed, Allotey et al. have subsequently demonstrated that only $5 \%$ of asymptomatic pregnant and recently pregnant women with COVID-19 exhibit altered sense of taste [34]. Given that only one woman tested positive in our cohort, inclusion of anosmia and or ageuisia as a symptom would not alter our results as her symptoms had resolved by the time she was tested. As the Samba-II process is not based on cycle time we are unable to comment on viral load for this patient. However Celik et al. have demonstrated that Covid-19 viral shedding from the upper respiratory tract has a mean duration of 17 days (up to a 
maximum of 83 days) but is not infectious beyond day 9 of illness [39].

A potential limitation of SAMBA II testing relates to financial implications as the machine costs $£ 35,000$ with test capsules costing $£ 35$ each. The financial cost implications of asymptomatic screening within maternity has not been evaluated. However, given the high infectivity of COVID-19, asymptomatic screening within a hospital setting will remain an important component so as to avoid nosocomial infection, prevent patient-to-staff infection, and to rationalise the use of full personal protective equipment. Another disadvantage is testing capacity, given that each machine can only handle only one test at a time, and each run lasting $1.5 \mathrm{~h}$. Our unit has mitigated this by running 20 machines simultaneously. Additional barriers have been manufacturing enough machines, reagents and cartridges for testing. Nonetheless SAMBA II has been procured by NHS England and is being implemented in over 100 sites nationally.

\section{Conclusion}

The Royal College for Obstetricians and Gynaecologists in the UK have recently published guidelines on testing for asymptomatic pregnant women attending maternity units [40]. These are broadly in line with our current practice but for the type of swab being offered (conventional lab based RT-PCR as opposed to rapid testing with the SAMBA II). Owing to the variable rates of asymptomatic carriage of COVID-19 in pregnant women, and the rapid turnaround time using the SAMBA II machine, we propose the introduction of SAMBA II or other point of care testing platforms in maternity units as an accurate and acceptable test to pregnant women requiring admission.

\section{Supplementary Information}

The online version contains supplementary material available at https://doi. org/10.1186/s12884-021-03653-4.

\section{Additional file 1.}

\section{Abbreviations}

NP: Nasopharyngeal; OP: Oropharyngeal; CUH: Cambridge University Hospitals NHS Foundation Trust; COVID-19: Coronavirus-19; TAT: Results turnaround time; RT-PCR: Real time quantitative fluorescence polymerase chain reaction; IQR: Interquartile range

\section{Acknowledgements}

We are grateful to all the pregnant women for their co-operation with COVID-19 screening during the pandemic.

\section{Authors' contributions}

$\mathrm{HC}$ conceived the study. HML, RG, RH and $H C$ designed the study. $\mathrm{RX}$ and $\mathrm{HC}$ screened titles and abstracts for inclusion and literature review. HC, RX and TP extracted and analysed data. HML helped interpret the study findings from a clinical viewpoint. $\mathrm{HC}$ and RX wrote the first draft, which all authors revised for critical content. All authors approved the final manuscript. $\mathrm{HC}$ is the guarantor. The guarantor had full access to all the data in the study, take responsibility for the integrity of the data and the accuracy of the data analysis, and had final responsibility for the decision to submit for publication. The corresponding author attests that all listed authors meet authorship criteria and that no others meeting the criteria have been omitted.

\section{Funding}

None.

\section{Availability of data and materials}

The datasets generated for the cohort study are not publically available due to current UK regulations with regards to data protection, but are available from the corresponding author on reasonable request. The datasets generated for the peak coronavirus prevalence rates can be found from international repositories listed in the references.

\section{Ethics approval and consent to participate}

This work was registered as service evaluation project (ID 3079). All women booked for maternity care at the Rosie Maternity Hospital are asked verbally whether they give their consent for data to be used for research and this is recorded in their computerised hospital records. We can therefore confirm that this is a formally approved method of consenting for use of data in research at the Rosie Maternity Unit. Identifiable data were removed from cases to ensure anonymity. Identifiable data were removed from cases to ensure anonymity. Additionally, in accordance with the United Kingdom National Health Service National Research Ethics Service guidance, neither individual informed consent nor formal research ethics committee review was required, because the study was undertaken by the direct clinical team using information collected in the course of routine care.

\section{Consent for publication}

Not applicable.

\section{Competing interests}

All authors have completed the ICMJE uniform disclosure form at wwW. icmje.org/coi_disclosure.pdf and declare: no support from any organisation for the submitted work; no financial relationships with any organisations that might have an interest in the submitted work in the previous three years, no other relationships or activities that could appear to have influenced the submitted work. Completed disclosure of interest forms are available to view online as supporting information.

\section{Author details}

${ }^{1}$ Department of Obstetrics \& Gynaecology, Rosie Maternity Hospital, Cambridge CB2 OSQ, UK. ${ }^{2}$ Department of Anaesthesia, Cambridge University NHS Hospitals Foundation Trust, Cambridge CB2 OQQ, UK. ${ }^{3}$ Department of Medicine, University of Cambridge, Cambridge CB2 OAW, UK.

Received: 28 October 2020 Accepted: 18 February 2021 Published online: 17 March 2021

\section{References}

1. WHO. Rolling updates on coronavirus disease (COVID-19). https://www.who. int/emergencies/diseases/novel-coronavirus-2019/events-as-they-happen. Accessed 1 Aug 2020

2. Huang C, Wang Y, Li X, Ren L, Zhao J, Hu Y, et al. Clinical features of patients infected with 2019 novel coronavirus in Wuhan, China. Lancet (London, England). 2020;395:497-506. https://doi.org/10.1016/S0140-6736(2 0)30183-5.

3. Hoffmann M, Kleine-Weber H, Schroeder S, Krüger N, Herrler T, Erichsen S, et al. SARS-CoV-2 Cell Entry Depends on ACE2 and TMPRSS2 and Is Blocked by a Clinically Proven Protease Inhibitor. Cell. 2020;181:271-80.e8. https:// doi.org/10.1016/j.cell.2020.02.052.

4. Lauer SA, Grantz KH, Bi Q, Jones FK, Zheng Q, Meredith HR, et al. The incubation period of coronavirus disease 2019 (COVID-19) from publicly reported confirmed cases: estimation and application. Ann Intern Med. 2020;172:577-82. https://doi.org/10.7326/M20-0504.

5. Zhao J, Yuan Q, Wang H, Liu W, Liao X, Su Y, et al. Antibody Responses to SARS-CoV-2 in Patients with Novel Coronavirus Disease 2019. Clin Infect Dis. 2020;71:2027-34. https://doi.org/10.1093/cid/ciaa344. 
6. Mlcochova P, Collier D, Ritchie A, Assennato SM, Hosmillo M, Goel N, et al. Combined point-of-care nucleic acid and antibody testing for SARS-CoV-2 following emergence of D614G spike variant. Cell Reports Medicine. 2020;1.

7. Buitrago-Garcia DC, Egli-Gany D, Counotte MJ, Hossmann S, Imeri H, Salanti $\mathrm{G}$, et al. The role of asymptomatic SARS-CoV-2 infections: rapid living systematic review and meta-analysis. 2020.

8. Sutton D, Fuchs K, D'Alton M, Goffman D. Universal Screening for SARS-CoV2 in Women Admitted for Delivery. New England J Med. 2020;382:2163-4. https://doi.org/10.1056/nejmc2009316.

9. Assennato SM, Ritchie AV, Nadala C, Goel N, Zhang H, Datir R, et al. Performance evaluation of the point-of-care SAMBA II SARS-CoV-2 Test for detection of SARS-CoV-2. medRxiv. 2020. https://doi.org/10.1101/2020. 05.24.20100990v3.

10. Collier DA, Assennato SM, Warne B, Sithole N, Sharrocks K, Ritchie A, et al. Point of care nucleic acid testing for SARS-CoV-2 in hospitalized patients: a clinical validation trial and implementation study. Cell Reports Medicine. 2020;1. https://doi.org/10.1016/j.xcrm.2020.100062.

11. Rivett L, Routledge M, Sparkes D, Warne B, Bartholdson J, Cormie C, et al. Screening of healthcare workers for SARS-CoV-2 highlights the role of asymptomatic carriage in COVD-19 transmission. eLife. 2020; epub ahead of print.

12. Sridhar S, Forrest S, Kean I, Young J, Scott JB, Maes M, et al. A blueprint for the implementation of a validated approach for the detection of SARS-Cov2 in clinical samples in academic facilities. bioRxiv. 2020;:2020.04.14.041319. https://doi.org/10.1101/2020.04.14.041319.

13. Fassett MJ, Lurvey LD, Yasumura L, Nguyen M, Colli JJ, Volodarskiy M, et al. Universal SARS-Cov-2 screening in women admitted for delivery in a large managed care organization. Am J Perinatol. 2020. https://doi.org/10.1055/s0040-1714060.

14. Gagliardi L, Danieli R, Suriano G, Vaccaro A, Tripodi G, Rusconi F, et al. Universal severe acute respiratory syndrome coronavirus 2 testing of pregnant women admitted for delivery in 2 Italian regions. Am J Obstet Gynecol. 2020;223:291-2. https://doi.org/10.1016/j.ajog.2020.05.017.

15. Herraiz I, Folgueira D, Villalaín C, Forcén L, Delgado R, Galindo A. Universal screening for SARS-CoV-2 before labor admission during Covid-19 pandemic in Madrid. J Perinat Med. 2020. https://doi.org/10.1515/jpm-2020-0236.

16. Naqvi M, Burwick RM, Ozimek JA, Greene NH, Kilpatrick SJ, Wong MS. Severe acute respiratory syndrome coronavirus 2 (SARS-CoV-2) universal testing experience on a Los Angeles labor and delivery unit. Obstet Gynecol. 2020; 136:235-6. https://doi.org/10.1097/AOG.0000000000003987.

17. LaCourse SM, Kachikis A, Blain M, Simmons LE, Mays JA, Pattison AD, et al. Low prevalence of SARS-CoV-2 among pregnant and postpartum patients with universal screening in Seattle, Washington. Clinical Infect Dis. 2020. https://doi.org/10.1093/cid/ciaa675

18. Ceulemans D, Thijs I, Schreurs A, Vercammen J, Lannoo L, Deprest J, et al. Screening for COVID-19 at childbirth: is it effective? Ultrasound Obstetrics Gynecol. 2020;56:113-4. https://doi.org/10.1002/uog.22099.

19. Miller ES, Grobman WA, Sakowicz A, Rosati J, Peaceman AM. Clinica implications of universal severe acute respiratory syndrome coronavirus 2 (SARS-CoV-2) testing in pregnancy. Obstet Gynecol. 2020;136:232-4. https:// doi.org/10.1097/AOG.0000000000003983.

20. Ochiai D, Kasuga Y, lida M, Ikenoue S, Tanaka M. Universal screening for SARS-CoV-2 in asymptomatic obstetric patients in Tokyo, Japan. In J Gynaecol Obstetrics. 2020;150:268-9. https://doi.org/10.1002/ijgo.13252.

21. Campbell KH, Tornatore JM, Lawrence KE, Illuzzi JL, Sussman LS, Lipkind HS, et al. Prevalence of SARS-CoV-2 among patients admitted for childbirth in southern Connecticut. JAMA. 2020;323. https://doi.org/10.1001/jama.2020.8904.

22. Khalil A, Hill R, Ladhani S, Pattisson K, O'Brien P. Severe acute respiratory syndrome coronavirus 2 in pregnancy: symptomatic pregnant women are only the tip of the iceberg. Am J Obstet Gynecol. 2020. https://doi.org/10.1 016/j.ajog.2020.05.005.

23. Yassa M, Yirmibes C, Cavusoglu G, Eksi H, Dogu C, Usta C, et al. Outcomes of universal SARS-CoV-2 testing program in pregnant women admitted to hospital and the adjuvant role of lung ultrasound in screening: a prospective cohort study. J Maternal-Fetal Neonatal Med. 2020:1-7. https:// doi.org/10.1080/14767058.2020.1798398.

24. Prabhu M, Cagino K, Matthews KC, Friedlander RL, Glynn SM, Kubiak JM, et al. Pregnancy and postpartum outcomes in a universally tested population for SARS-CoV-2 in New York City: a prospective cohort study. BJOG. 2020. https://doi.org/10.1111/1471-0528.16403.

25. Dória M, Peixinho C, Laranjo M, Mesquita Varejão A, Silva PT. Covid-19 during pregnancy: a case series from an universally tested population from the north of Portugal. Eur J Obstet Gynecol Reprod Biol. 2020;250:261-2. https://doi.org/10.1016/j.ejogrb.2020.05.029.

26. Sutton D, Fuchs K, D'Alton M, Goffman D. Universal screening for SARS-CoV2 in women admitted for delivery. N Engl J Med. 2020;382:2163-4. https:// doi.org/10.1056/NEJMc2009316.

27. Buckley A, Bianco A, Stone J. Universal testing of patients and their support persons for severe acute respiratory syndrome coronavirus 2 when presenting for admission to labor and delivery at Mount Sinai Health System. Am J Obstet Gynecol MFM. 2020:100147. https://doi.org/10.1016/J.A JOGMF.2020.100147.

28. Vintzileos WS, Muscat J, Hoffmann E, John NS, Vertichio R, Vintzileos AM, et al. Screening all pregnant women admitted to labor and delivery for the virus responsible for coronavirus disease 2019. Am J Obstet Gynecol. 2020; 223:284-6. https://doi.org/10.1016/j.ajog.2020.04.024.

29. London V, McLaren R, Atallah F, Cepeda C, McCalla S, Fisher N, et al. The relationship between status at presentation and outcomes among pregnant women with COVID-19. Am J Perinatol. 2020;37:991-4. https://doi.org/10.1 055/s-0040-1712164

30. Johns Hopkins University of Medicine Coronavirus Resource Center. https:// coronavirus.jhu.edu/data.

31. GOV.UK Coronavirus (COVD-19) in the UK. https:/coronavirus.data.gov.uk/cases.

32. WHO Coronavirus Disease (COVID-19) Dashboard. 2020. https://covid19.who.int/.

33. Breslin N, Baptiste C, Gyamfi-Bannerman C, Miller R, Martinez R, Bernstein K, et al. Coronavirus disease 2019 infection among asymptomatic and symptomatic pregnant women: two weeks of confirmed presentations to an affiliated pair of New York City hospitals. Am J Obstet Gynecol MFM. 2020:100118. https://doi.org/10.1016/j.ajogmf.2020.100118.

34. Allotey J, Stallings E, Bonet M, Yap M, Chatterjee S, Kew T, et al. Clinical manifestations, risk factors, and maternal and perinatal outcomes of coronavirus disease 2019 in pregnancy: living systematic review and metaanalysis. The BMJ. 2020;370:3320. https://doi.org/10.1136/bmj.m3320.

35. Goldenberger D, Leuzinger K, Sogaard KK, Gosert R, Rolo T, Naegele K, et al. Brief validation of the novel GeneXpert Xpress SARS-CoV-2 PCR assay. J Virol Methods. 2020; https://www.ncbi.nlm.nih.gov/pmc/articles/PMC7351036/.

36. Commision CNH. Chinese Clinical Guidance for COVID-19 Pneumonia Diagnosis and Treatment (7th edition) 抗击新冠肺炎. http://kjfy. meetingchina.org/msite/news/show/cn/3337.html. Accessed 24 Jun 2020.

37. Liao J, He X, Gong Q, Yang L, Zhou C, Li J. Analysis of vaginal delivery outcomes among pregnant women in Wuhan, China during the COVID-19 pandemic. Int J Gynecol Obstet. 2020;150:53-7. https://doi.org/10.1002/ ijgo.13188.

38. GOV.UK. Statement from the UK Chief Medical Officers on an update to coronavirus symptoms. 2020. https://www.gov.uk/government/news/sta tement-from-the-uk-chief-medical-officers-on-an-update-to-coronavirussymptoms-18-may-2020. Accessed 20 Dec 2020.

39. Cevik M, Tate M, Lloyd O, Maraolo AE, Schafers J, Ho A. SARS-CoV-2, SARSCoV, and MERS-CoV viral load dynamics, duration of viral shedding, and infectiousness: a systematic review and meta-analysis. The Lancet Microbe. 2020;5247:1-10. https://doi.org/10.1016/s2666-5247(20)30172-5.

40. RCOG. Principles for the testing and triage of women seeking maternity care in hospital settings, during the COVID-19 pandemic. 2020. https:// www.rcog.org.uk/globalassets/documents/guidelines/2020-08-10-principlesfor-the-testing-and-triage-of-women-seeking-maternity-care-in-hospitalsettings-during-the-covid-19-pandemic.pdf. Accessed 15 Aug 2020.

\section{Publisher's Note}

Springer Nature remains neutral with regard to jurisdictional claims in published maps and institutional affiliations. 